\title{
Professor M. Peaker, B.Sc., Ph.D., F.I. Biol.
}

Professor Malcolm Peaker, who is presently Head of the Physiology Department of The Hannah Research Institute, has been appointed Director of the Institute in succession to Professor J. A. F. Rook. He took up his appointment on 1 April 1981. Professor Peaker became Head of the Institute's Physiology Department in 1978 having spent the previous 10 years in the Physiology Department of the Agricultural Research Council's Institute of Physiology, Babraham, Cambridge. There he engaged in research into mechanisms associated with secretion of components of the aqueous phase of milk and, in a fruitful collaboration with the late $\mathrm{Dr}$ J. L. Linzell, into the control of milk secretion and mammary gland function. At The Hannah Research Institute he has developed further this interest in mammary gland physiology and function.

Professor Peaker was educated at the University of Sheffield where he obtained his bachelor's degree in Zoology and at the University of Hong Kong where he gained his doctorate.

\section{Professor J. A. F. Rook, D.Sc., F.I. Biol., F.R.S.C., F.R.S.E.}

Professor J. A. F. Rook, Director of The Hannah Research Institute since 1971, has been appointed Second Secretary of the Agricultural Research Council. He took up his duties on 1 January 1981 in succession to Dr G. W. Cooke, C.B.E., F.R.S. who has retired. As Second Secretary he will be responsible to the Secretary of the Council, Dr R. Riley, F.R.S., for all scientific matters.

Professor Rook was born in Yorkshire and educated at the University College of Wales at Aberystwyth. He has had a continuing interest in animal metabolism and lactation and engaged in research in both fields of study at The Hannah Research Institute and the National Institute for Research in Dairying. Before returning to The Hannah Research Institute he was Professor of Agricultural Chemistry at the University of Leeds from 1965 to 1970 . He is succeeded as Director of The Hannah Research Institute by Professor Malcolm Peaker. 